\title{
PENGARUH KEPEMIMPINAN, PENGAWASAN DAN SANKSI HUKUMAN TERHADAP KEDISIPLINAN KERJA PEGAWAI DI SEKRETARIAT DAERAH KOTA BIMA
}

\author{
SYAHRIAL NURYADIN ${ }^{1}$ \\ AGUSDIN $^{2}$ \\ DJOKO SUPRAYETNO 3
}

\begin{abstract}
This study aimed to analyze the influence of leadership, supervision systems and punitive sanctions against the level of employee discipline in the Regional Secretariat Bima. There are three independent variables in this study; leadership, supervision, and punitive sanction against the level of employee discipline. In this study population is 240 people with a sample of 100 respondens selected by the simple random sampling. Simultaneously the results of the study concluded that leadership variable have an influence on work discipline but not significant, control variable have an influence on work discipline but not significant and punitive sanctions variable positive and significant impact on employee discipline. Punitive sanctions is a variable that has the most dominant influence compared with other variables. Of the research results can be recommended a few things, that isemployee discipline would be improved if good leadership, good supervision and sanctions fair punishment can be combined and synchronized with well by the leadership, either in the form of rules written and in it's application.
\end{abstract}

\section{Keyword: Leadership, Supervision, Sanction, Employee Disciplin}

\section{PENDAHULUAN}

Sumber daya manusia (SDM) merupakan salah satu sumber keunggulan kompetitif dan merupakan aset penting dalam suatu organisasi yang menjadi salah satu bagian dari proses perencanaan strategis. Yuniarsih dan Suwatno (2009) menyatakan bahwa sumber daya manusia merupakan faktor sentral dalam suatu organisasi. Bagaimanapun bentuk serta tujuannya, organisasi dibuat berdasarkan visi untuk kepentingan manusia dan dalam pelaksanaan misinya dikelola dan diurus oleh manusia. Jadi, sumber daya manusia merupakan faktor strategis dalam kegiatan organisasi.

Perwujudan pemerintah yang bersih dan berwibawa diawali dengan penegakan kedisiplinan nasional dilingkungan Aparatur Sipil Negara yaitu PNS. Hasibuan (2010:53) mengungkapkan bahwa kedisiplinan adalah kesadaran dan kesediaan seseorang menaati semua peraturan dalam organisasi dan norma-norma yang berlaku. Dalam upaya meningkatkan kedisiplinan kerja pegawai negeri sipil, pemerintah telah membuat suatu regulasi dengan adanya Peraturan Pemerintah Nomor. 30 Tahun 1980 yang telah diperbaharui dengan Peraturan Pemerintah Nomor. 53 Tahun 2010 tentang peraturan disiplin pegawai negeri sipil. Kemudian pemerintah menerbitkan Undang-Undang Nomor 5 Tahun 2014

\footnotetext{
${ }^{1}$ Mahasiswa Program Magister Manajemen Pascasarjana Universitas Mataram

${ }^{2}$ Dosen Pembimbing Utama, Dosen Program Magister Manajemen Pascasarjana Universitas Mataram

${ }^{3}$ Dosen Pembimbing Pendamping, Dosen Program Magister Manajemen Pascasarjana Universitas Mataram
} 


\section{JMURAL MAGISTER MANAJEMEN UNIVERSITAS MATARAM \\ Juni 2016}

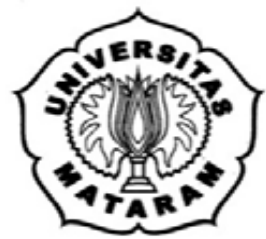

tentang ASN pada paragraf 11 pasal 86 tentang disiplin Aparatur Sipil Negara. Tetapi pada umumnya PNS dirasakan masih kurang mematuhi peraturan kedisiplinan pegawai sehingga dapat menghambat kelancaran pemerintahan dan pembangunan nasional.

Penelitian ini dilakukan karena adanya riset gap tentang beberapa perbedaan hasil penelitian yang dilakukan oleh beberapa peneliti terdahulu baik itu mengenai pengaruh kepemimpinan terhadap kedisiplinan kerja, pengawasan terhadap kedisiplinan kerja, maupun sanksi hukuman terhadap kedisiplinan kerja. Seperti penelitian Rasyidi (2013) dengan judul penelitian Variabel-variabel yang Mempengaruhi Disiplin Pegawai Pada Dinas Sosial Provinsi Kalimantan Timur menyimpulkan bahwa pengawasan berpengaruh positif dan signifikan terhadap disiplin kerja. Penelitian ini berbeda dengan penelitian Bismala dan Agustina (2014) tentang Dampak Pengawasan dan Kepuasan Kerja dalam Memengaruhi Kedisiplinan Kerja Pegawai PT. Perkebunan Nusantara IV (PERSERO) Medan menemukan bahwa pengawasan tidak berpengaruh terhadap kedisiplinan kerja karyawan. Penelitian lainnya antara Rumiris (2013) dan Nugraheni (2012) yang meneliti hubungan sanksi hukuman terhadap disiplin menyimpulkan dua hal berbeda, Rumiris dalam penelitiannya menemukan bahwa sanksi hukuman berpengaruh signifikan terhadap disiplin sedangkan Nugraheni dalam penelitiannya menunjukkan bahwa sanksi hukuman tidak berpengaruh terhadap disiplin kerja.

Hal lain yaitu berdasarkan fenomena yang terjadi di sekertariat daerah Kota Bima mengungkapkan bahwa adanya masalah indisipliner pegawai di sekertariat Daerah Kota Bima seperti pegawai sering membolos, datang kerja terlambat, dan tidak menaati peraturan dalam organisasi disebabkan karena bawahan melihat, mengamati dan kebanyakan mencontoh prilaku pimpinanydaang dirasa belim memberikan contoh dan tauladan yang baik dalam hal kedisiplian bagi pegawai. Hal ini menimbulkan asumsi negatif pegawai terhadap atasan. Selain itu pemimpin dirasa belum melakukan pengawasan yang efektif terhadap kerja pegawai, dan penerapan peraturan-peraturan tentang pengawsan terhadap kedisiplinan kerja pegawai belum maksimal, serta penerapan dan pemberian sanksi kepada pegawai yang melanggar kedisiplinan dinilai belum ada ketegasan, sehingga hal tersebut tidak memberikan efek jera bagi pegawai dalam melakukan tindakan indisipliner.

\section{TUJUAN PENELITIAN}

Dari latar belakang dan rumusan masalah diatas, adapun tujuan yang diharapkan dari penelitian adalah sebagai berikut :

1. Untuk menganalisis pengaruh antara faktor kepemimpinan, pengawasan dan sanksi hukuman terhadap kedisiplinan kerja pegawai sekertariat daerah Kota Bima?

2. Untuk menganalisis manakah diantara faktor kepemimpinan, pengawasan dan sanksi hukuman yang paling dominan berpengaruh terhadap kedisiplinan kerja pegawai di sekertariat daerah Kota Bima. 


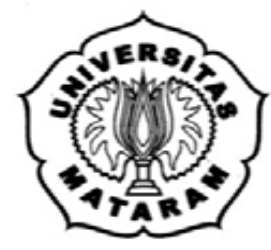

\section{LANDASAN TEORI}

\subsection{Kedisiplinan Kerja}

Menurut Hasibuan (2014:193) bahwa kedisiplinan adalah kesadaran dan kesediaan seseorang mentaati semua peraturan perusahaan dan norma-norma yang berlaku. Sastrohardiwiryo (2002:130) menyatakan kedisiplinan yaitu suatu sikap menghormati, menghargai, patuh dan taat terhadap peraturan-peraturan yang berlaku, baik yang tertulis maupun yang tidak tertulis serta sanggup menjalankannya dan tidak mengelak untuk menerima sanksi-sanksinya apabila ia melanggar tugas dan wewenang yang diberikan kepadanya. Menurut Viethzal (2004:443) mengemukakan bahwa kedisiplinan yang baik mencerminkan besarnya tanggung jawab terhadap tugas yang diberikan kepadanya hal ini mendorong gairah kerja dan semangat kerja dan terwujudnya tujuan organisasi, kariawan, serta masyarakat pada umumnya.

Berdasarkan pendapat ahli tersebut, dapat disimpulkan bahwa Kedisiplinan kerja dalam penelitian ini adalah tentang kesadaran dan tanggung jawab pegawai terhadap tugas yang diemban sebagai aparatur yang tercermin dalam sikap mental dan perbuatan perorangan maupun kelompok yang berupa kepatuhan dan ketaatan terhadap aturan dan ketentuan yang berlaku.

Adapun faktor-faktor yang mempengaruhi kedisiplinan kerja menurut Hasibuan $(2014 ; 194)$ antara lain adalah :

1. Tujuan dan Kemampuan

2. Teladan Pimpinan

3. Balas Jasa

4. Keadilan

5. Waskat

6. Sanksi Hukuman (Punishment)

7. Ketegasan

8. Hubungan kemanusiaan

Moekijat (2010) menyatakan indikator yang dapat digunakan untuk mengkaji disiplin kerja karyawan adalah:

1) Tingkat absensi atau kehadiran

2) Ketaatan terhadap peraturan

3) Kepatuhan atau kewajiban terhadap perintah

4) Ketaatan terhadap jam kerja

5) Kepatuhan berpakaian seragam

6) Kepatuhan dalam penggunaan dan pemeliharaan sarana dan prasarana kantor

7) Bekerja sesuai prosedur kantor.

\subsection{Kepemimpinan}

Veithzal (2004:443), menyatakan bahwa Kepemimpinan adalah proses mempengaruhi atau memberi contoh dari pemimpin kepada pengikutnya dalam upaya mencapai tujuan organisasi. Menurut Amirullah dan Haris Budiono (2004:245) kepemimpinan merupakan orang yang memiliki wewenang untuk memberikan tugas, mempunyai kemampuan untuk 


\section{JMUNAL MAGISTER MANAJEMEN UNIVERSITAS MATARAM UNRAM \\ Juni 2016}

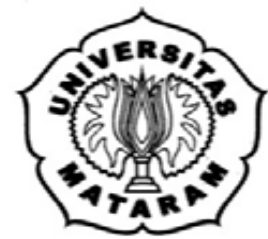

membujuk atau mempengaruhi orang lain (bawahan) melalui pola hubungan baik guna mencapai tujuan yang telah ditentukan. Selanjutnya menurut Amini (2004:140) kepemimpinan dapat diartikan sebagai suatu keadaan dimana suatu individu melakukan suatu tindakan sesuai dengan kesepakatan. Menurut Rivai dan Mulyadi dalam Teguh Sriwidadi dan Oey Charlie (2011) Kepemimpinan adalah sebagai proses mengarahkan dan mempengaruhi aktivitas-aktivitas yang ada hubungannya dengan pekerjaan para anggota kelompok. Dan kemudian menurut Stephen P. Robins dalam Irham Fahmi (2013:68) mengatakan kepemimpinan adalah kemampuan untuk mempengaruhi suatu kelompok kearah tercapainya tujuan. Ardana dkk (2009:89) mendefinisikan kepemimpinan adalah proses mempengaruhi aktivitas dari individu atau kelompok untuk mencapai tujuan dalam situasi tertentu.

Dari bebrapa pendapat diatas dapat disimpulkan bahwa kepemimpinan adalah aktualisasi sikap dan prilaku pimpinan yang dapat menjadi tauladan atau dapat dijadikan contoh bagi pegawai dalam melakukan kegiatan atau prilaku mereka sehari-hari dalam bekerja.

Menurut Rivai (2009), bahwa proses kepemimpinan akan berlangsung efektif bila mana kepribadian pemimpin memiliki beberapa criteria sebagai berikut : taqwa terhadap Tuhan Yang Maha Esa, memiliki integritas (jujur,etis,arif,rendah hati), antusiasme, komunikatif, mampu memotivasi, mampu memecahkan massalah, mampu membina hubungan baik dengan siapapun, ketegasan, keteladanan, berpengetahuan luas, inisiatif, bertanggung jawab dalam pengambilan keputusan, berkedisiplinan dan memelihara kesehatan jasmani dan rohani.

\subsection{Pengawasan}

Pengawasan adalah tindakan nyata dan efektif untuk mencegah/ mengetahui kesalahan, membetulkan kesalahan, memelihara kedisiplinan, meningkatkan prestasi kerja, mengaktifkan peranan atasan dan bawahan, menggali sistem-sistem kerja yang paling efektif, serta menciptakan sistem internal kontrol yang terbaik dalam mendukung terwujudnya tujuan perusahaan, karyawan, dan masyarakat (Hasibuan, 2014). Menurut Terry dan Leslie (2010) pengawasan adalah proses mengevaluasi pelaksanaan kerja dengan membandingkan pelaksanaan aktual dengan apa yang diharapkan serta mengambil tindakan yang perlu.

Adapun indikatornya menurut Robert J. Mokler dalam Amirillah dan Budiono (2004 : 298) adalah sebagai berikut:

a. Kegunaan pengawasan, meliputi : Menetapkan standar dan metode untuk; pengukuran prestasi; Mengukur prestasi; Membandingkan prestasi, sesuai dengan standar; Mengambil tindakan perbaikan

b. Tujuan pengawasan, meliputi : Akurat; Secara ekonomi realistic; Tepat waktu; Realistik secara organisasi.

\subsection{Sanksi Hukuman}

Menurut Veithzal Rivai dan Ella Jauvani (2014) sanksi adalah hukuman disiplin yang dijatuhkan pimpinan organisasi kepada pegawai yang melanggar peraturan disiplin yang telah diatur pimpinan organisasi. Menurut Mangkunegara (2000:130) "punishment adalah ancaman hukuman yang bertujuan untuk memperbaiki kinerja karyawan pelanggar, memelihara peraturan yang berlaku dan memberikan pelajaran kepada pelanggar. Menurut 


\section{JMM JURNAL MAGISTER MANAJEMEN \\ UNIVERSITAS MATARAM \\ Juni 2016}

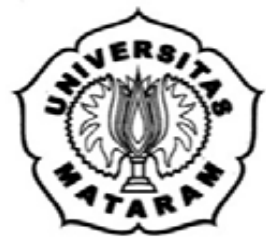

Ivancevich, Konopaske dan Matteson dalam Gania (2006:226) “punishment didefinisikan sebagai tindakan menyajikan konsekuensi yang tidak menyenangkan atau tidak diinginkan sebagai hasil dari dilaukannya prilaku tertentu. Dari definisi diatas dapat disimpilkan bahwa sanksi hukuman (punishment) adalah konsekuensi yang akan didapat bagi pelanggar kedisiplinan setelah sebelumnya diberikan peringatan dan ancaman sebagai penunjang dalam merubah sikap dan prilaku dalam berdisiplin agar penegakan aturan kedisiplinan tetap berjalan dengan baik.

Pada umumnya sebagai pegangan pemimpin meskipun tidak mutlak, tingkat dan jenis sanksi disiplin kerja yang dikemukakan oleh Siswanto Sastrohadiwiryo (2003:293-294) terdiri atas sanksi disiplin berat, sanksi disiplin sedang dan sanksi disiplin ringan.

1. Sanksi disiplin berat, misalnya :

- Demosi jabatan yang setingkat lebih rendah dari jabatan atau pekerjaan yang diberikan sebelumnya

- Pembebasan dari jabatan atau pekerjaan untuk dijadikan sebagai tenaga kerja biasa bagi memegang jabatan

- Pemutusan hubungan kerja dengan hormat atas permintaan sendiri tenaga kerja yang bersangkutan

- Pemutusan hubungan dengan tidak hormat sebagai tenaga kerja diorganisasi atau perusahaan

2. Sanksi disiplin sedang, misalnya :

- Penundaan pemberian kompensasi yang sebelumnya telah direncanakan sebagaimana tenaga kerja lain

- Penurunan upah atau gaji sebesar satu kali upah atau gaji yang biasanya diberikan harian, mingguan, atau bulanan

- Penundaan program promosi bagai bagi tenaga kerja yang bersangkutan pada jabatan yang lebih tinggi

3. Sanksi disiplin ringan, misalnya :

- Teguran lisan kepada tenaga kerja yang bersangkutan

- Teguran tertulis

- Pernyataan tidak puas secara tertulis.

\section{Kerangka Konseptual}

faktor-faktor yang mempengaruhi kedisiplinan kerja menurut Hasibuan $(2014 ; 194)$ antara lain adalah : Tujuan dan Kemampuan; Teladan Pimpinan; Balas Jasa; Keadilan; Waskat; Sanksi Hukuman (Punishment); Ketegasan; Hubungan kemanusiaan. 


\section{$J M M$ UNRAM \\ JURNAL MAGISTER MANAJEMEN \\ UNIVERSITAS MATARAM \\ Juni 2016}

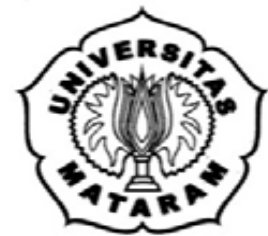

Gambar 4.1.Kerangka Konseptual

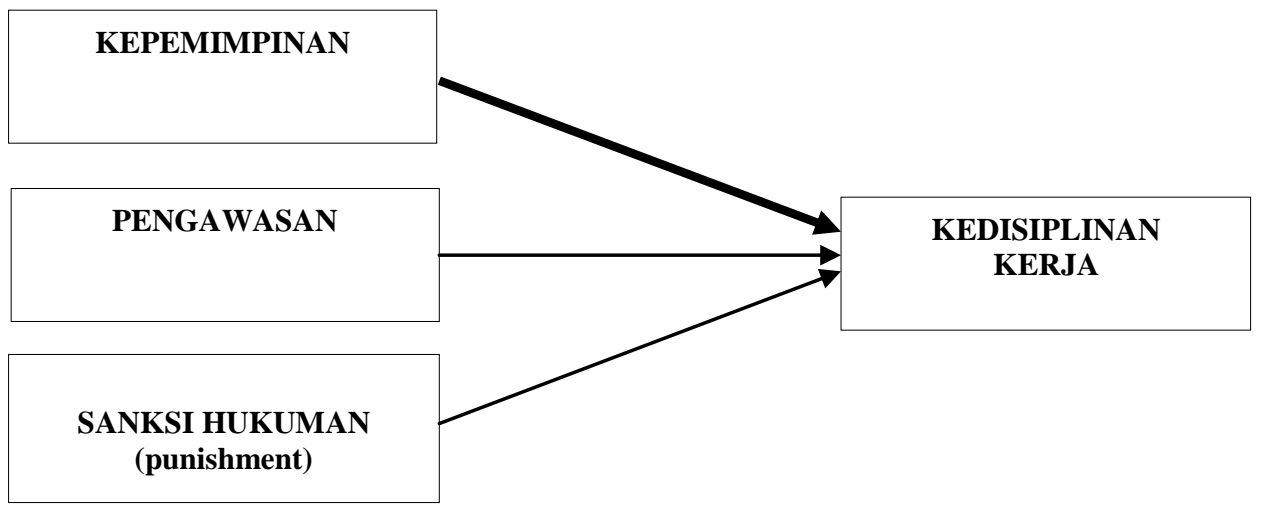

Gambar 2.1. Kerangka Konseptual Penelitian

Keterangan :

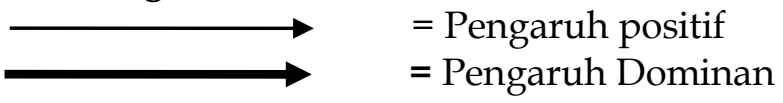

\section{Metodologi Penelitian}

Jenis penelitian yang digunakan dalam penelitian ini adalah penelitian Asosiatif atau sebab akibat (kausal). Penelitian asosiatif yaitu penelitian yang mengkaji hubungan dari satu atau dua variable lainnya (Sugiyono 2014). Metode penelitian ini akan digunakan untuk mengetahui pengaruh variabel-variabel kepemimpinan, pengawasan dan Sanksi Hukuman (punishment) sebagai variabel Independen terhadap kedisiplinan kerja Pegawai sebagai variabel Dependen.

Populasi adalah wilayah generalisasi yang terdiri atas subjek atau objek yang mempunyai kuantitas dan karakteristik tertentu yang ditetapkan oleh peneliti untuk dipelajari dan kemudian ditarik kesimpulannya (Sugiyono, 2014:148) berdasarkan konsep tersebut, maka yang menjadi populasi dalam penelitian ini adalah seluruh Pegawai Negeri Sipil Sekertariat Daerah Kota Bima, yaitu sejumlah 240 orang. Teknik pengambilan sampel dalam penelitian ini menggunakan teknik Probability Sampling, yaitu teknik pengambilan sampel yang memberikan peluang yang sama bagi setiap unsur (anggota) populasi untuk dipilih menjadi anggota sampel (Sugiyono, 2014 :152). Berdasarkan rumus diatas berarti jumlah sampel yang diambil adalah sebanyak 100 orang. Total jumlah sampel tersebut sangat memadai. Adapun dari 100 orang responden dipilih dengan menggunakan teknik Simple Random Sampling. Dikatakan simple (sederhana) karena pengambilan anggota sampel dari populasi dilakukan secara acak tanpa memperhatikan strata yang ada dalam populasi itu (Sugiyono, 2014: 152). Teknik ini digunakan karena tindakan indisipliner bisa terjadi pada seluruh pegawai tanpa memperhatikan strata.

Dalam penelitian ini, metode pengumpulan data interview berupa wawancara tidak terstruktur, yaitu wawancara bebas dimana peneliti tidak menggunakan pedoman wawancara yang telah tersusun seara sistematis dan lengkap untuk pengumpulan datanya. Pedoman 


\section{JMURAL MAGISTER MANAJEMEN UNIVERSITAS MATARAM

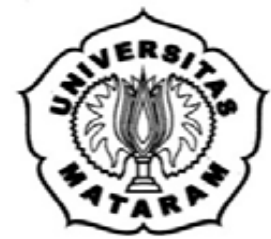

wawancara yang digunakan hanya berupa garis-garis besar permasalahan yang ditanyakan. Sugiyono (2014:228). Alat pengumpulan data yang digunakan dalam penelitian ini adalah Koesioner. Kuisioner dalam penelitian ini berupa pertanyaan dengan jumlah 41 item pertanyaan. Item pertanyaan tentang kedisiplinan kerja diambil dari teori Moekijat (2010), kepemipinan dari teori Rivai (2009), pengawasan dari teori Robert J. mokler dalam Amrilah dan Budiono (2004) dan Sanksi Hukuman dari teori Sastrohadiwiryo (2003).

Alat uji statistik yang digunakan untuk menganalisis hipotesis dalam penelitian ini adalah Analisis Regresi Berganda (Multyple Regression Analysis) untuk menguji variabel bebas yang terdiri dari kepemimpinan, Sanksi Hukuman (punishment), dan pengawasan terhadap variabel terikat (Kedisiplinan kerja pegawai Sekertariat Daerah Kota Bima). Analisis regresi linear berganda dipergunakan dalam penelitian ini karena variabel terikat dipengaruhi oleh lebih dari satu variabel bebas atau variabel penjelas. Uji hipotesis Koefisien Determinasi.

6. HASIL PENELITIAN

6.1. Deskripsi Karakteristik Responden

Hasil penelitian menunjukan :

1. Gambaran responden berdasarkan jenis kelamin laki-laki sebanyak 59 orang responden, lebih besar dari responden yang berjenis kelamin perempuan yang berjumlah 41 orang responden. Jumlah pria memiliki jumlah lebih banyak karenya mayoritas pegawai di secretariat daerah Kota Bima berjenis kelamin laki-laki yaitu dengan perbandingan $60 \%$ pria dan $40 \%$ wanita.

2. Gambaran responden berdasarkan umur yang jumlahnya paling banyak berada pada rentang umur antara 26 - 35 tahun, yaitu sebanyak 51 orang atau sebesar $51 \%$. Hal ini dikarenakan sebagian besar pegawai di Sekretariatdaerah Kota Bima lebih banyak diisi oleh pegawai yang tergolong masih muda dan kebanyakan dari mereka adalah sebagai staf. Sedangkan responden yang jumlahnya paling sedikit berada pada rentang umur 46 tahun keatas yaitu sebanyak 7 orang atau sebesar $7 \%$. Hal ini dikarenakan pegawai yang berumur lebih dari 46 tahun adalah pegawai yang telah menduduki jabatan seperti staf ahli, asisten maupun kepala bagian.

3. Gambaran responden berdasarkan tingkat pendidikan S1 berjumlah 78 orang dan yang memiliki jenjang pendidikan S2 berjumlah 11 orang. Hal ini menunjukan bahwa jumlah responden terbanyak yaitu pada jenjang pendidikan Sarjana (S1) yaitu sebanyak 78 orang atau sebesar 78\%, ini dikarenakan responden yang menjadi pegawai di Sekretariatdaerah Kota Bima adalah rata-rata berpendidikan S1 dan diterima sebagai pegawai dengan status sarjana golongan III/a, dan kebanyakan dari mereka merupakan staf, namun ada bebeapa orang dari mereka yang memiliki jabatan sebagai kasubag pada eselon IV/a.

4. Gambaran responden berdasarkan masa kerja 6 sampai dengan 15 tahun sebanyak 72 orang atau sebesar $72 \%$ dan merupakan responden yang jumlahnya paling banyak. Hal ini dikarenakan rata-rata pegawai yang bekerja di Sekretariatdaerah Kota Bima merupakan pegawai yang berpendidikan sarjana dan mereka memiliki rata-rata masa kerja 6-15 tahun. Kemudian responden yang masa kerjanya antara 16 sampai 25 tahun sebanyak 4 orang atau sebesar $4 \%$ yang merupakan responden yang jumlahnya paling 


\section{JMURAL MAGISTER MANAJEMEN UNIVERSITAS MATARAM \\ Juni 2016}

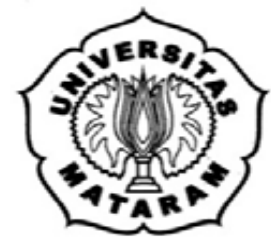

sedikit dan responden yang masa kerjanya lebih dari 26 tahun adalah seanyak 5 orang atau sebesar $5 \%$.

6.2. Hasil Analisis

6.3. Uji Hipotesis I

6.3.1. Uji Simultan

Hasil uji hipotesis secara simultan didapat nilai $\mathrm{F}$ hitung sebesar 16,867, sedangkan nilai F tabel sebesar 2,70. Karena F hitung lebih besar daripada F tabel, maka terdapat pengaruh pengaruh yang signifikan secara simultan antara variabel kepemimpinan, pengawasan dan sanksi hukuman terhadap variabel kedisiplinan kerja. Hasil perhitungan regresi linear berganda dengan menggunakan program SPSS seperti yang terlihat pada tabel 4.18. menunjukan bahwa nilai $r$ square sebesar 0,345 atau sebesar 34,5\%. Hal ini berarti 34,5\% kedisiplinan kerja pegawai dpengaruhi oleh kepemimpinan, pengawasan dan sanksi hukuman, sedangkan sisanya yaitu 65,5\% kedisiplinan kerja dipengaruhi oleh faktor - faktor atau variabel lainnya.

Hal ini sejalan dengan beberapa teori yang diungkapkan oleh Hasibuan (2010) menjelaskan bahwa kepemimpinan sangat berperan dalam menentukan kedisiplinan pegawai karena pemimpin dijadikan teladan dan panutan oleh para bawahannya. Hasibuan juga menyatakan bahwa kedisiplinan juga dipengaruhi oleh pengawasan yang artinya adalah tindakan nyata dan paling efektif dalam mewujudkan kedisiplinan pegawai dalam suatu organisasi. Kemudian menurut Fathoni (2012) sanksi hukuman berperan penting dalam memelihara kedisiplinan pegawai. Dengan sanksi hukuman yang semakin berat, maka pegawai akan semakin takut melanggar peraturan-peraturan dalam organisasi.

Berdasarkan dari beberapa teori yang diuraikan diatas, dapat dilihat bahwa kepemimpinan, pengawasan dan sanksi hukuman sama-sama memiliki pengaruh terhadap kedisiplinan kerja, yang artinya secara simultan memiliki pengaruh. Hal ini sejalan dengan penelitian yang dilakukan oleh Susilaningsih (2008) yang menyimpulkan bahwa kepemimpinan, motovasi, pengawasan, diklat dan sanksi hukuman secara serempak berpengaruh terhadap tingkat kedisiplinan pegawai.

Memperhatikan hasil penelitian ini bahwa sudah sepantasnya para pegawai dalam melaksanakan tugas dan kewajibannya selaku abdi negara dan abdi masyarakat bersikap dan berprilaku disiplin sesuai dengan peraturan-peraturan yang berlaku dalam organisasi, karena kedisiplinan merupakan modal dasar yang harus dimiliki oleh setiap pegawai, terutama bagi seorang pimpinan dalam organisasi, karena pada hakikatnya seorang pimpinan selalu menjadi contoh teladan dan panutan bagi bawahanya. Kedisiplinan juga merupakan modal dalam membentuk pribadi manusia yang berdaya saing, sehingga dapat memberikan pelayanan yang optimal kepada masyarakat dan merupakan syarat utama bagi keberhasilan organisasi dalam mencapai tujuannya. Kedisiplinan kerja akan terwujud apabila pimpinan dapat mengkombinasikan, mensinkronkan dan menjalankan kepemimpinan, pengawasan dan snksi hukuman secara baik dan maksimal, bukan saja dalam bentuk aturan tertulis, namun dalam penerapannya harus sesuai dengan apa yang tertuang dalam aturan yang telah dibuat, karena pada hakikatnya aturan akan melindungi kita apabalia kita mengikuti aturan. 


\section{JMURAL MAGISTER MANAJEMEN UNIVERSITAS MATARAM

\author{
Juni 2016
}

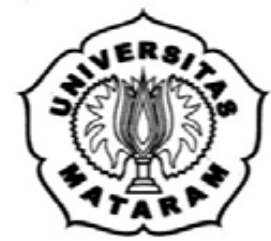

\subsubsection{Uji Parsial}

Dalam analisis regresi linear berganda secara parsial bahwa ketiga variabel dalam penelitian ini memiliki pengaruh terhadap kedisiplinan kerja pegawai di Sekertariat Daerah Kota Bima. Untuk memberikan pemahaman terhadap hasil analisis ini, dapat dilihat pada uraian berikut ini :

\subsubsection{Pengaruh Kepemimpinan terhadap Kedisiplinan Kerja}

Dari hasil olah data variabel kepemimpinan dalam penelitian ini ditemukan hasil rata rata sebesar 3,7 . hal ini berarti bahwa persespsi pegawai yang berkaitan dengan aktualisasi sikap dan prilaku pimpinan dalam kegiatan atau prilaku mereka sehari-hari dalam bekerja pada Sekertariat Daerah Kota Bima dinilai sudah efektif, seperti dalam hal integritas, antusias maupun dalam mengkomunikasikan hal-hal yang berkaitan dengan organisasi. Namun juga ada beberapa hal yang menurut pandangan penulis masih membutuhkan perbaikan dan peningkatan prilaku kepemimpinan, seperti dalam hal kejujuran, ketegasan, keteladanan maupun kedisiplinan yang juga mempengaruhi persepsi pegawai.

Hasil penelitian menunjukan bahwa kepemimpinan merupakan variabel bebas yang memiliki nilai $\mathrm{t}$ hitung sebesar 1,322 yang nilainya lebih kecil dari $\mathrm{t}$ tabel dengan tingkat signifikansi 0,05 (5\%) yaitu sebesar 1,985. Ini berarti H0 diterima. Sehingga dapat ditarik kesimpulan bahwa variabel kepemimpinan tidak berpengaruh secara signifikan terhadap variabel kedisiplinan kerja pegawai. Hal ini sejalan dengan penelitian yang dilakukan oleh Utari (2015) yang menyimpulkan bahwa variabel kepemimpinan memiliki pengaruh positif tapi tidak signifikan terhadap kedisiplian kerja.

Hasil penelitian ini bertolak belakang dengan teori yang dikemukakan oleh Hasibuan (2010) yang menjelaskan bahwa kepemimpinan sangat berperan dalam menentukan kedisiplinan kerja pegawai, karena pemimpin dijadikan teladan dan panutan oleh bawahannya. Fenomena yang terjadi di sekertariat daerah Kota Bima, bahwa adanya masalah indisipliner pegawai di Sekertariat Daerah Kota Bima seperti pegawai sering membolos, datang kerja terlambat, dan tidak menaati peraturan dalam organisasi disebabkan karena bawahan melihat, mengamati dan kebanyakan mencontoh prilaku pimpinan yang dirasa belum memberikan contoh dan tauladan yang baik dalam hal kedisiplinan kerja pegawai. Hal ini yang menimbulkan asumsi negatif pegawai terhadap atasan, sehingga mengakibatkan pegawai cenderung tidak mampu bekerjasama dan kedisiplinan kerja pegawai dirasa masih rendah.Veithzal (2004:443), menyatakan bahwa kepemimpinan adalah proses memengaruhi atau memberi contoh dari pemimpin kepada pengikutnya dalam upaya mencapai tujuan organisasi.

Adapun dari para pegawai yang memberikan alasan bahwa mereka akan mematuhi aturan walaupun ada atau tanpa adanya pimpinan yang mengawasi jika mereka dikenai sanksi hukuman seperti pemotongan honor maupun TKD. Hasil ini juga menunjukan bahwa hipotesis yang diungkapkan penulis dalam penelitian ini yang menyatakan bahwa variabel kepemimpinan berpengaruh signifikan tidak terbukti. Namun ada juga beberapa hasil penelitian yang menunjukan bahwa kepemimpinan memiliki pengaruh terhadap kedisiplinan kerja, seperti hasil penelitian yang dilakukan oleh Fachri dan Irawan (2010) yang 


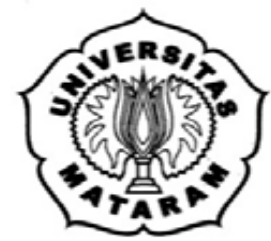

menunjukkan bahwa teladan pimpinan mempengaruhi kedisiplinan kerja. Selain itu Penelitian yang dilakukan oleh Rasyidi, dkk (2013) juga menunjukkan hasil bahwa kepemimpinan berpengaruh secara signifikan terhadap disiplin kerja pegawai.

\subsubsection{Pengaruh Pengawasan Terhaadap Kedisiplinan Kerja}

Hasil olah data variabel pengawasan dalam penelitian ini ditemukan hasil rata - rata sebesar 3,8. Jadi persepsi pegawai tentang suatu upaya yang sistematik yang dilakukan oleh sebuah organisasi untuk menetapkan standar kinerja pada perencanaan dalam merancang sistem umpan balik informasi, untuk membandingkan kinerja aktual dengan standar yang telah ditentukan, untuk menetapkan apakah telah terjadi suatu penyimpangan, serta untuk mengambil tindakan perbaikan yang diperlukan untuk menjamin bahwa semua sumber daya dalam suatu organisasi telah digunakan seefektif dan seefisien mungkin guna mencapai tujuan organisasi yang ada di lingkungan Sekertariat Daerah Kota Bima bisa dikatakan efektif.

Penelitian menunjukan bahwa pengawasan merupakan variabel bebas yang memiliki nilai $t$ hitung sebesar 0,270 yang nilainya lebih kecil dari $t$ tabel dengan tingkat signifikansi 0,05 (5\%) yaitu sebesar 1,985. Ini berarti H0 diterima. Sehingga dapat ditarik kesimpulan bahwa variabel pengawasan tidak berpengaruh secara signifikan terhadap variabel kedisiplinan kerja pegawai. Dengan kata lain jika dilihat dari nilai signifikansi pada tabel 4.18. untuk variabel pengawasan (X2) adalah sebesar 0,788, nilai ini lebih besar dari standar signifikansi yaitu sebesar 0,05 (5\%), yang artinya variabel pengawasan tidak memiliki pengaruh yang signifikan terhadap variabel kedisiplinan kerja. Hasil penelitian ini sejalan dengan penelitian yang dilakukan oleh Bismala (2014) yang menyimpulkan bahwa pengawasan tidak berpengaruh terhadap kedisiplian kerja karyawan. Namun penelitian ini berbeda dengan penelitian yang dilakukan oleh Marzolina (2013) yang menemukan bahwa pengawasan berpengaruh positif dan signifikan terhadap kedisiplinan kerja. Demikian juga penelitian ini berbeda dengan hasil penelitian Rasyidi, dkk (2013) yang menyimpulkan bahwa pengawasan melekat terbukti berpengaruh secara signifikan terhadap kedisiplinan kerja pegawai.

Menurut pendapat Hasibuan (2014) menyatakan bahwa pengawasan adalah tindakan nyata dan paling efektif dalam mewujudkan kedisiplinan pegawai dalam suatu organisasi. Demikian juga Pemerintah Kota Bima telah mengeluarkan Peraturan Walikota Nomor 4 Tahun 2015 tentang disiplin kerja ASN yang tertuang dalam pasal 19 berisi tentang pengawasan dan pengendalian. Pemerintah Kota Bima memiliki keinginan yang kuat yang ditunjukkan oleh komitmen dalam meningkatkan kualitas pengawasan untuk meningkatkan kedisiplinan kerja pegawai. Namun menurut pandangan penulis, dalam penerapan Peraturan Walikota No 4 Tahun 2015 tersebut belum bisa dilakukan secara maksimal, sehingga hal ini dirasa belum cukup untuk menyadarkan dan merubah pola sikap dan prilaku pegawai yang masih melakukan tindakan indisipliner yang mengakibatkan masih adanya kekosongan jam kerja dan ketidaktepatan waktu dalam menyelesaikan pekerjaan. Sehingga hasil penelitian ini berbeda dengan pendapat Hasibuan (2014) serta berbeda dengan kebanyakan hasil penelitian yang menemukan hasil bahwa pengawasan memengaruhi kedisiplinan kerja pegawai. Kedisiplinan tidak muncul karena adanya pengawasan saja, namun kedisiplinan juga bisa 


\section{JMURAL MAGISTER MANAJEMEN UNIVERSITAS MATARAM UNRAM \\ Juni 2016}

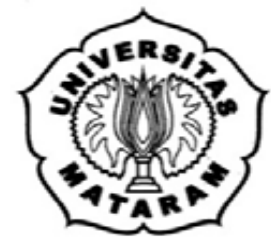

muncul karena adanya kesadaran diri serta komitmen untuk selalu berdisiplin dalam melaksanakan aktifitasnya. Jadi pengawasn masih harus lebih ditingkatkan lagi agar kedisiplinan kerja dapat diwujudkan secara maksimal. Selain itu organisasi juga harus menyoroti penyebab rendahnya kedisiplinan dari faktor-faktor lain, misalnya mptivasi, komitmen, budaya maupun faktor lainnya yang diduga memberikan pengaruh terhadap kedisiplinan.

\subsubsection{Pengaruh Sanksi Hukuman terhadap Kedisiplinan Kerja}

Dilihat dari nilai rata - rata data deskriptif di atas, bahwa nilai rata - rata dari jawaban responden terhadap variabel sanksi hukuman adalah sebesar 3,8. Nilai ini merupakan nilai rata - rata tertinggi dibandingkan dengan dua variabel lainnya yaitu kepemimpinan dan pengawasan. Ini berarti bahwa hampir seluruh responden mengungkapkan bahwa persepsi pegawai tentang konsekuensi yang akan didapatkan bagi pegawai yang melakukan pelanggaran kedisiplinan pada Sekertariat Daerah Kota Bima dapat dikatakan berat.

Hasil penelitian menunjukan bahwa sanksi hukuman merupakan variabel bebas yang memiliki nilai $\mathrm{t}$ hitung sebesar 3,954 yang nilainya lebih besar dari $\mathrm{t}$ tabel dengan tingkat signifikansi 0,05 (5\%) yaitu sebesar 1,985. Ini berarti H0 ditolak. Sehingga dapat ditarik kesimpulan bahwa variabel sanksi hukuman memiliki pengaruh yang signifikan terhadap variabel kedisiplinan kerja pegawai.Dengan kata lain jika dilihat dari nilai signifikansi pada tabel 4.18. untuk variabel sanksi hukuman (X3) adalah sebesar 0,000, nilai ini lebih kecil dari standar signifikansi yaitu sebesar 0,05 (5\%). yang artinya variabel sanksi hukuman memiliki pengaruh yang signifikan terhadap variabel kedisiplinan kerja.

Pemerintah Kota Bima telah menerapkan peraturan pemerintah no 53 tahun 2010 tentang disiplin PNS dengan cukup baik, hal ini dilihat pula dengan adanya komitmen pemerintah Kota Bima dalam hal kedisiplinan kerja ditandai dengan diterbitkannya Peraturan Walikota Bima Nomor 23 Tahun 2011 tentang Pemberian Tambahan Penghasilan Berdasarkan Disiplin Kerja PNS dan CPNS. Ini memberikan motivasi bagi pegawai karena setiap apa yang mereka kerjakan memiliki konsekuensi berupa reward dan punishment, jadi bagi pegawai yang memiliki kedisiplinan kerja yang tinggi akan mendapatkan penghasilan yang berbeda dengan pegawai yang belum memiliki kedisiplinan kerja yang tinggi. Oleh karena itu dibutuhkan komitmen pimpinan organisasi dalam penerapan, pemberian serta penegakan aturan secara konsisten, adil dan transparan mengenai apa yang boleh dan apa yang tidak boleh dilakukan. Hal ini sejalan dengan penelitian yang dilakukan oleh Augustiani (2013) yang menunjukan bahwa dampak dari sanksi hukuman disiplin yaitu kepatuhan dan kesadaran pegawai terhadap peraturan disiplin meningkat.

\subsubsection{Uji Hipotesis 2 (Pengaruh Dominan)}

Variabel sanksi hukuman memiliki pengaruh yang paling dominan dibandingkan dengan dua variabel lainnya yaitu kepemimpinan dan pengawasan. Maka dapat dijelaskan bahwa hipotesis awal dalam penelitian ini yang menyatakan bahwa variabel kepemimpinan lebih dominan pengaruhnya dibandingkan dengan variabel pengawasan dan sanksi hukuman terhadap kedisiplinan kerja pegawai di Sekretariat Daerah Kota Bima tidak terbukti, karena 


\section{JMURAL MAGISTER MANAJEMEN UNIVERSITAS MATARAM UNRAM \\ Juni 2016}

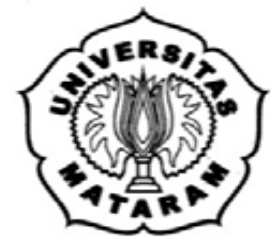

berdasarkan hasil penelitian dan penilaian responden ditemukan variabel sanksi hukuman mempunyai $t$ hitung paling besar, yaitu 3,954 lebih besar dari nilai $t$ hitung variabel lainnya. Jadi dapat dikatakan bahwa apabila komitmen pimpinan organisasi dalam hal penerapan, pemberian serta penegakan aturan dilakukan secara konsisten, adil dan transparan mengenai apa yang boleh dan apa yang tidak boleh dilakukan, maka hal tersebut akan meningkatkan kedisiplinan kerja pegawai di Sekertariat Daerah Kota Bima.

Fenomena yang terjadi di sekrretariat daerah Kota Bima menunjukan bahwa kebanyakan dari pegawai pegawai akan lebih patuh terhadap aturan apabila sanksi yang berat ditegakan, seperti demosi, penundaan promosi jabatan maupun pemotongan TKD. Sementara kepemimpinan dan pengawasan hanya di patuhi oleh pegawai apabila pimpinan melihat dan mengamati prilaku mereka stetiap hari, dan apabila pimpinan tidak ada di tempat dan tidak ada pengawasan yang intensif, maka kebanyakan dari pegawai tidak akan mengikuti aturan yang berlaku dalam organisasi, sehingga mengakibatkan rendahnya kedisiplinan kerja.

Hal ini sejalan dengan pendapat yang dikemukakan oleh Fathoni (2012) yang mengemukakan bahwa sanksi hukuman berperan penting dalam memelihara kedisiplinan pegawai. Pendapat ini didukung oleh Hasibuan (2010) yang menyatakan bahwa salah satu faktor yang mempengaruhi kedisiplinan adalah sanksi hukuman. Selanjutnya Rumiris S (2013) dalam penelitiannya menunjukan bahwa reward dan punishment berpengaruh positif terhadap kedisiplinan kerja, dan punishment merupakan variabel paling tinggi (dominan) pengaruhanya terhadap kedisiplinan.

\section{KESIMPULAN}

Berdasarkan hasil analisis penelitian yang memperngaruhi kedisiplinan kerja pegawai lingkup Sekertariat Daerah Kota Bima dapat ditarik kesimpulan sebagai berikut :

1. Hasil penelitian menunjukan bahwa variabel kepemimpinan dan pengawasan tidak memiliki pengaruh yang signifikan terhadap kedisiplinan kerja pegawai di sekertariat daerah Kota Bima, sedangkan variabel sanksi hukuman memiliki pengaruh yang signifikan terhadap kedisiplinan kerja pegawai di Sekretariat Daerah Kota Bima.

2. Hasil Penelitian ini menunjukan bahwa variabel sanksi hukuman memiliki pengaruh yang dominan dibandingkan dengan variabel kepemimpinan dan pengawasan terhadap kedisiplinan kerja pegawai di sekertariat daerah Kota Bima. Hal ini dilihat dari nilai variabel sanksi hukuman lebih besar dari nilai variabel kepemimpinan dan pengawasan. Selain itu juga berdasarkan fenomena yang terjadi di secretariat daerah Kota Bima memperlihatkan bahwa pegawai hanya taat aturan hanya pada saat adanya pimpinan yang mengawasi, dan ketika pimpinan tidak ada yang mengawasi, mereka akan kembali melakukan tindakan indisipliner. Pegawai akan taat pada aturan dan akan lebih takut apabila mereka diberikan sanksi hukuman yang berat, seperti demosi, penundaan promosi jabatan, maupun pemotongan TKD.

\section{SARAN}

Berdasarkan kesimpulan dalam penelitian ini, penulis memberikan saran baik untuk kepentingan Pemerintah Kota Bima dalam pengambilan kebijakan maupun sebagai bahan masukan dan kajian untuk penelitian selanjutnya yang terkait dengan penelitian ini, antara lain adalah sebagai berikut : 


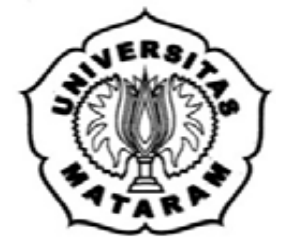

1. Bagi para pimpinan dalam organisasi diharapkan dapat kiranya memberikan perhatian serius terhadap peningkatan kedisiplinan kerja pegawai. Pimpinan diharapkan dapat menciptakan pola perilaku serta memberikan contoh teladan kepemimpinan yang lebih baik dalam organisasi sehingga dapat diterima oleh bawahan yang pada akhirnya akan tercipta kedisiplinan kerja yang tinggi dalam organisasi dan membuat suatu hubungan kerjasama yang baik dan bersinergi antara atasan dan bawahan.

2. Secara umum pengawasan yang dilakuakan sudah baik, namun demikian masih perlu adanya evaluasi dan peningkatan serta perbaikan dalam hal penerapan Peraturan Walikota Bima Nomor 4 Tahun 2015 agar menjadi lebih baik terutama pada peningkatan kedisiplinan diri atau ketertiban para pegawai agar lebih patuh dan disiplin terhadap peraturan yang ada dalam organisasi. Sehingga dapat memberikan hasil yang lebih maksimal dalam menjalankan tugas dan tanggung jawab demi tercapainya tujuan organisasi.

3. Bagi para peneliti yang ingin melanjutkan atau mengembangkan penelitian ini nantinya dianjurkan melihat atau meneliti variabel lainnya yang mempengaruhi kedisiplinan, seperti pendidikan dan pelatihan, motivasi, pemberian kompensasi, dan variabel - variabel laninya. Selain itu juga diharapkan untuk melakukan survey awal terlebih dahulu sehingga penelitian selanjutnya diharapkan akan lebih baik dari penelitian ini.

4. Kedisiplinan kerja akan terwujud apabila pimpinan dapat mengkombinasikan, mensinkronkan dan menjalankan kepemimpinan, pengawasan dan snksi hukuman secara baik dan maksimal, bukan saja dalam bentuk aturan tertulis, namun dalam penerapannya harus sesuai dengan apa yang tertuang dalam aturan yang telah dibuat, karena pada hakikatnya aturan akan melindungi kita apabalia kita mengikuti aturan.

\section{DAFTAR PUSTAKA}

Amirullah dan Haris Budiyono, 2004. Pengantar Manajemen.Yogyakarta : Graha Ilmu.

Amini, 2004. Prilaku Organisasi. Edisi Revisi. Bandung : Citapustaka Media.

Ardana, K., Mujiati, N.W., dan Anak Sriathi, A.A., 2009. Perilaku Keorganisasian. Yogyakarta : Graha Ilmu.

Asmiarsih, Tety. 2006. Pengaruh Pengawasan terhadap Kedisiplinan Kerja pada Kantor Badan Kepegawaian Daerah Kabupaten Brebes. Skripsi Jurusan Ekonomi Universitas Negeri Semarang

Devano, Sony dan Siti Kurnia Rahayu, 2006, Perpajakan: Konsep, Teori dan isu, Kencana, Jakarta.

Fahmi, Irham. 2013. Prilaku Organisasi. Bandung : Alfabeta

Gibson,J.L.,Ivancevich,J.M.,Donnely,J.H., 2009,Organisasi,Perilaku,Struktur dan proses,Jakarta: Binaputra Aksara Publisher.

Hadari, Nawawi. 2000. Manajemen Sumber Daya Manusia. Yogyakarta: Gadjah Mada University Press 


\section{JMM JURNAL MAGISTER MANAJEMEN

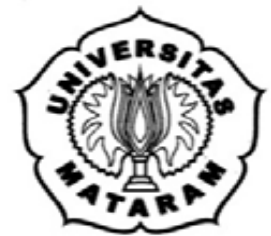

Handayani, Retno. 2008. Analisis Faktor - Faktor yang Mempengaruhi

Underpricing Pada Penawaran Umum Perdana di BEJ Tahun 2000

- 2006. Tesis Program Pasca Sarjana. Universitas Diponegoro.

Hasibuan, Malayu. (2010). Manajemen Sumber Daya Manusia (Edisi Revisi). Jakarta: PT. Bumi Aksara.

Hasibuan, \& Malayu S. P 2014, Manajemen Sumber Daya Manusia, Jakarta: PT.BumiAksara

Hani Handoko, 2010, Manajemen Personalia E Sumberdaya Manusia, Edisi kedua, BPFE UGM Yogyakarta. 